\title{
Aksiologi Ilmu Pengetahuan dan Manfaatnya bagi Manusia
}

\author{
Rosnawati ${ }^{1}$, Ahmad Syukri², Badarussyamsi ${ }^{3}$, Ahmad Fadhil Rizki ${ }^{4}$. \\ ${ }^{1}$ Program Doktoral UIN Jambi, Indonesia \\ 2,3 Jurusan Manajemen Pendidikan Islam UIN Jambi, Indonesia \\ ${ }^{4}$ Pendidikan Agama Islam STAI Miftahul Tanjungpinang, Indonesia \\ E-mail: zahraalgiffari66@yahoo.com¹, ahmadsyukriss@uinjambi.ac.id². \\ badarussyamsi@uinjambi.ac.id ${ }^{3}$. Ahmadfadhilrizki1995@gmail.com4.
}

\begin{abstract}
Abstrak
Artikel ini membahas tentang hakikat aksiologi ilmu pengetahuan bagi manusia. Aksiologi yang dimaksud dalam penelitian ini adalah studi filosofi yang menjelaskan tentang nilai dan manfaat dari ilmu bagi kehidupan manusia. Aksiologi adalah ilmu yang mempelajari hakikat dan manfaat yang sebenarnya dari pengetahuan dan ilmu pengetahuan itu tidak ada yang sia - sia kalau kita bisa memanfaatkannya dengan sebaik baiknya untuk kepentingan manusia secara umum. Rumusan masalah yang diangkat adalah bagaimana hakikat aksiologi, ilmu pengetahuan serta manfaatnya bagi kehidupan manusia. Tehnik pengambilan data dan analisis data dengan menggunakan penelitian kepustakaan. Substansi ilmu pengetahuan sangat berpengaruh pada manfaatnya. Oleh karena itu, ilmu pengetahuan harus bermuatan positif dan memiliki kegunaan serta manfaat bagi manusia karena jika ilmu pengetahuan memiliki konten negative lalu dimanfaatkan oleh oknumoknum yang tidak bertanggungjawab maka akan mendatangkan mudharat bagi manusia. Tulisan ini menjelaskan tentang fungsi dan kegunaan ilmu pengetahuan yang telah memberikan manfaat yang sebesar-besarnya bagi kehidupan manusia, karena ilmu pengetahuan merupakan instrumen penting dalam setiap proses pembangunan sebagai usaha untuk mewujudkan kemashlahatan hidup manusia seluruhnya. IImu pengetahuan dapat dimanfaatkan sebagai sarana untuk meningkatkan taraf hidup manusia dan kesejahteraannya dengan menitik beratkan pada kodrat dan martabat untuk kepentingan manusia.
\end{abstract}

Kata kunci: aksiologi; ilmu pengetahuan; manusia.

\begin{abstract}
This article discusses the nature of the axiology of science and its benefits for humans. The axiology referred to in this research is a philosophical study that explains the value and benefits of science for human life. Axiologi is a science that studies the true nature and benefits of knowledge and science is not vain if we can use it as well as possible for the benefit of human in general. The formulation of the problem raised is how the nature of axiology, science and its benefits for human life. Data collection techniques and data analysis using library research. The substance of science is very dependent on its benefits. Therefore, science must be positively charged and have us has negative content and then is used by irresponsible persons, it will bring harm to humans. The basic goal is to find the truth of the existing facts or wherever possible there is certainty of scientific truth. This paper describes the functions and uses of science that has provided the greatest benefit to human life, where science is an important instrument in every development process as an effort to realize the benefit of human life entirely. Science can be used as a means to improve the standard of living of humans and their welfare by focusing on nature and dignity for the benefit of humans.
\end{abstract}

Keywords: axiology; science; human.

\section{Pendahuluan}

Pendidikan sebagai ilmu pengetahuan merupakan tolok ukur bagi suatu bangsa dalam menentukan kemajuan bangsanya. Pendidikan sebagai sarana kemajuan bangsa inilah yang mendorong setiap individu untuk bisa mengakses dunia pendidikan sekaligus bisa mengabdi terhadap bangsa dan negara. Bagi siapapun yang sudah memperoleh pendidikan maka akan bisa merasakan suatu kebahagiaan dalam arti penting dari ilmu pengetahuan yang diperolehnya ketika mampu ditransformasikan kepada masyarakat secara umum. Kedudukan pendidikan sebagai sebuah kewajiban bagi setiap individu untuk selalu berusaha mengejar dan berproses secara formal maupun non formal akan melahirkan individu yang bisa membuat peradaban bangsa bisa menjadi 
maju.

Ketika pengetahuan dapat diimplementasikan dalam banyak pengajaran dan praktik kehidupan manusia di lembaga pendidikan, pengetahuan yang diperoleh akan memiliki substansi yang nyata. Sains membutuhkan pemikiran yang menyeluruh (mendalam) untuk dapat dipahami dengan baik. Perkembangan ilmu pengetahuan mau tidak mau akan dibarengi dengan perkembangan bidang filsafat, karena keseimbangan antara ilmu pengetahuan dan filsafat akan menjadi sarana pengontrol aksiologi (nilai) ilmiah, yang akan mengantarkan pada peradaban manusia yang sama berharganya.

Filsafat adalah sejenis kegiatan manusia yang menggunakan akal budi untuk memahami secara mendalam dan menjawab semua pertanyaan yang berkaitan dengan transendensi, humanisme, dan lingkungan manusia guna memperoleh pengetahuan tentang bagaimana mewujudkan hakikat filsafat melalui akal budi manusia.

Filsafat bukan sekedar rangkaian proses berpikir, tetapi yang terpenting adalah berpikir secara mendalam melalui penggambaran ciri-ciri berpikir (radikal), universalitas, konseptualitas, koherensi dan konsistensi, sistemikitas, kelengkapan, kebebasan dan tanggung jawab. Dapat dipahami bahwa masalah yang dipecahkan berdasarkan ciri-ciri di atas adalah persis di mana ungkapan filosofis itu berada. Pada tahap ini, filsafat dapat dijelaskan sebagai proses penerapan pemikiran dan metode tertentu sesuai dengan objeknya. Dalam hal ini, konsep filsafat dapat didefenisikan sebagai sebuah proses, upaya, dan metode untuk bergerak maju dengan menggunakan pemikiran kritis dan radikal untuk menemukan kebenaran.

Meskipun filsafat sendiri sangat dekat dengan kehidupan manusia, namun filsafat biasanya dianggap sebagai ilmu yang sangat abstrak. Beberapa kalangan berpendapat bahwa filsafat merupakan mata pelajaran yang kurang populer karena dianggap sebagai ilmu yang sulit dan membutuhkan pemikiran. Kegiatan filsafat melibatkan seluruh pemikiran manusia, konsisten dan bertanggung jawab. Dalam aktivitas nalar, para filosof berusaha mengungkap realitas. Kegiatan mengungkapkan realitas ini membutuhkan bahasa sebagai alat untuk memahami realitas.

Manusia sebagai makhluk Tuhan yang diberikan potensi akal untuk digunakan berfikir serta proses belajar berangkat dari sebuah pengalaman yang dimilikinya. Melalui akal serta pengalaman tersebut akhirnya manusia bisa menghasilkan ilmu pengetahuan. Akal inilah yang bisa membedakan antara manusia dengan makhluk lainnya dan mengantarkan manusia untuk mengetahui sesuatu. Rasa ingin tahu yang muncul dari manusia inilah yang menjadi asal mula pengetahuan. Disaat manusia memikirkan tentang eksistensinya terkait dari mana manusia ada, bagaimana manusia itu ada serta untuk apa manusia ada dan kemana setelah manusia tidak ada? Maka pertanyaanpertanyaan inilah membutuhkan sebuah perenungan serta pemikiran secara mendalam dan jawabannya itulah membutuhkan pemikiran filsafat.

Filsafat adalah ilmu pengetahuan yang bersifat ekstensial yang mempunyai arti sangat erat hubungannya dengan kehidupan sehari-hari, karena dapat dianggap sebagai motor penggerak dalam kehidupan manusia. Dalam konteks filsafat hidup, orang selalu mempertimbangkan hal-hal penting sebelum menetapkan keputusan untuk berperilaku (Mohammad Adib, 2010). Dengan demikian, ilmu pengetahuan dapat dimaknai sebagai sekumpulan pengetahuan manusia yang bersifat ilmiah dengan menggunakan metode ilmiah. Oleh karena itu, ilmu pengetahuan disebut juga sebagai pengetahuan ilimiah. Eksistensi ilmu pengetahuan dapat mengantarkan setiap manusia untuk meraih tujuan yang ingin dicapai. Dengan ilmu pengetahuan seseorang akan mampu membedakan yang benar dan salah, merupakan sarana menuju surga serta meningkatkan derajat seseorang sekaligus merupakan hal yang paling berharga selain harta. Dengan ilmu akan menjadikan seseorang bisa lebih arif dan bijaksana dalam menghadapi setiap persoalan yang terjadi.

\section{Metode}

Artikel ini menggunakan metode kualitatif dengan menggunakan library research yaitu dengan menelaah sumber bacaan yang ada hubungannya dengan kajian yang di bahas, serta dengan menggunakan studi dokumen hasil-hasil penelitian sebelumnya yang ada hubungannya dengan filsafat ilmu. Pengumpulan data di lakukan dengan menelusuri buku-buku bacaan, jurnal ilmiah yang terbit di google scholar, digital library, serta perpustakaan.

\section{Pembahasan}

\section{a. Pengertian Aksiologi}

Pengertian secara etimologi, kata aksiologi berasal dari bahasa Yunani yang terdiri dari dua kata yaitu axios yang berarti layak atau pantas dan logos yang berarti ilmu atau studi mengenai. Selain itu, nilai juga berasal dari bahasa latin Valere yang berarti berarti berguna, mampu akan, berdaya, berlaku atau kuat yang bermakna kualitas sesuatu hal yang menjadikannya dapat disukai, 
diinginkan bermanfaat atau menjadi objek kepentingan. Namun juga bisa bermakna sebagai apa yang dihargai, dinilai tinggi, atau dihargai sebagai suatu kebaikan (Zaprulkhan, 2016).

Berdasarkan pengertian menurut bahasa sebagaimana tersebut di atas, maka penegertian aksiologi secara istilah adalah merupakan studi yang berkaitan dengan teori tentang nilai atau studi segala sesuatu yang dapat bernilai atau memberikan manfaat. Nilai merupakan suatu fenomena tapi tidak berada dalam suatu ruang dan waktu. Selain itu, nilai juga merupakan esensi-esensi logis dan dapat dipahami melalui akal.

Istilah aksiologi dalam pandangan agama Islam bukanlah merupakan hal yang baru karena Nabi Muhammad selalu memintanya setiap pagi dengan berdoa "Allahumma inni asaluka 'ilman naafi'an wa rizqan thoyyiban wa 'amalan mutaqabbalan" artinya: "Yaa Allah sungguh aku memohon kepadaMu ilmu yang bermanfaat, rezeki yang baik dan amal yang diterima" (HR. Ibnu As-Sunni dan Ibnu Majah). Jadi aksiologi akan terkait dengan kemanfaatan daripada ilmu yang membicarakan tentang value atau nilai suatu kehidupan. Istilah aksiologi yang berasal dari bahasa Yunani yang terdiri dari dua kata yaitu axion yang berarti nilai dan logos yang berarti teori (Dani Vardiansyah, 2008). Dengan demikian, aksiologi dapat didefenisikan sebagai teori tentang nilai (Dani Vardiansyah, 2008). Pembahasannya mencakup tiga hal berupa tindakan moral yang melahirkan etika, ekspresi keindahan yang melahirkan estetika dan kehidupan social politik yang melahirkan filsafat sosial politik. Nilai adalah sifat atau kualitas yang melekat pada suatu objek tapi bukan objek itu sendiri. Dari pengertian secara etimologi, makna aksiologi menurut Kattsof adalah sains mengenai hakikat nilai yang biasanya dilihat dari sudut pandang kefilsafatan (Louis Kattsoff, 2004).

Berdasarkan defenisi dari aksiologi sebagaimana disebutkan diatas, dapat dipahami bahwa aspek aksiologi dari filsafat mempelajari dan menjelaskan tentang segala sesuatu yang berhubungan dengan moral dan nilai- nilai.

Selanjutnya, aksiologis dalam wacana filsafat mengacu pada persoalan etika (moral) dan estetika (keindahan).

1) Etika

Pengertian secara etimologi, etika berasal dari bahasa Yunani, yaitu berasal dari kata ethikos atau ethos yang berarti adat, kebiasaan dan praktik (Frans Magnis S, 2006). Secara umum etika merupakan teori mengenai tingkah laku atau tindak-tanduk perbuatan manusia yang dipandang dari aspek nilai baik dan burukyang dapat ditentukan oleh akal. Dalam pandangan para ahli, etika secara garis besar dapat diklasifikasi ke dalam tiga bidang studi yaitu: etika deskriptif, etika normative, dan metaetika (Zaprulkhan, 2016).

a) Etika deskriptif, menguraikan dan menjelaskan kesadaran dan pengalaman moral secara deskriptif yang digolongkan dalam bidang ilmu pengetahuan empiris dan berkaitan dengan sosiologi.

b) Etika normative, memberikan petunjuk atau penuntun dalam mengambil keputusan yang menyangkut baik dan buruk atau benar dan salah.

c) Metaetika, merupakan studi terhadap didiplin etika yang menyelidiki makna istilah-istilah normative yang diungkapkan lewat pernyataan etis yang membenarkan atau menyalahkan suatu tindakan

\section{2) Estetika}

Estetika adalah ilmu yang membahas bagaimana keindahan dapat terbentuk, serta bagaimana dapat merasakannnya. Sebuah keindahan yang sudah terbentuk tentunya harus dapat dirasakan oleh banyak orang. Istilah estetika berasal dari bahasa Yunani, aesthesis yang berarti pencerapan inderawi, pemahaman intelektual atau pengamatan spiritual.

Wacana aksiologi merupakan salah satu bagian penting dari filsafat yang membahas dan menerangkan terkait persoalan nilai, mengapa sesuatu itu dinilai baik atau buruk, dan dinilai indah atau tidak indah serta berhubungan dengan nilai-nilai, etika dan estetika. Jadi ilmu pengetahuan bukan hanya bersifat teoritis semata melainkan juga berdampak praktis secara fungsional dalam kehidupan umat manusia.

Dalam wacana aksiologi, terdapat tiga macam teori mengenai nilai.

1) Teori objektivitas nilai. Teori ini adalah teori sudut pandang, yang menunjukkan bahwa nilai adalah objektif dalam arti nilai. Nilai ini dapat secara konsisten didukung oleh argumentasi yang cermat dan rasional karena merupakan yang terbaik. Nilai, norma, dan cita-cita adalah elemen yang ada dalam objek, atau ada dalam realitas objektif, atau diberikan kepada objek melalui daya tarik (Milton D. Hunnex, 2004).

2) Teori subjektivitas nilai, yaitu pandangan bahwa nilai-nilai seperti kebaikan, kebenaran, keindahan, tidak ada dalam dunia real objektif tetapi merupakan perasaan-perasaan, sikap-sikap pribadi dan merupakan penafsiran atas kenyataan (Lorens Bagus, 2002). Pandangan ini mereduksi penentuan nilai ke dalam statemen yang berkaitan dengan suikap mental terhadap suatu objek atau situasi. Nilai memiliki realitas hanya sebagai suatu keadaan pikiran terhadap 
suatu objek. Subjektivisme aksiologi cenderung mengabsahkan teori etika sebagai hedonisme, naturalisme. Hedonisme yaitu sebuah teori yang menyatakan kebahagiaan sebagai kriteria nilai. Sedangkan naturalism, meyakini bahwa suatu nilai dapat direduksi ke dalam sebuah pernyataan psikologis. Nilai tergantung pada dan hubungan dengan pengalaman manusia tentangnya, nilai tidak memiliki realitas yang independent (Milton D. Hunnex, 2004).

3) Relativisme nilai. Relativisme nilai adalah pandangan yang memiliki beberapa prinsip sebagai berikut: a). bahwa nilai-nilai bersifat relatif karena berhubungan dengan preferensi (sikap, keinginan, ketidaksukaan, perasaan, selera, kecenderungan dan sebagainya), baik secara social maupun pribadi yang dikondisikan oleh lingkungan, kebudayaan, kebudayaan, atau keturunan; b) bahwa nilai-nilai berbeda secara radikal dalam banyak hal dari suatu kebudayaan ke kebudayaan lainnya; c) bahwa pernilaian-penilaian seperti benar atau salah, baik atau buruk, tepat atau tidak tepat, tidak dapat diterapkan padanya; dan d) bahwa tidak ada, dan tidak dapat ada nilai-nilai universal, mutlak, dan objektif manapun yang diterapkan pada semua orang pada segala waktu (Lorens Bagus, 2002: 718).

Teori ini mendapatkan kritik tajam sebab pandangan ini secara keliru menyamakan nilai objektif dengan penilaian pribadi subjek khususnya dengan perasaan-perasaan subjek. Oleh karena itu, relativisme jatuh subjektivisme nilai. Menurut teori ini bahwa setiap individu (subjek) menentukan nilai-nilainya sendiri. Dengan alasan inilah, sebagian filsuf menyatakan dengan tegas bahwa nilai adalah esensi non temporal dan hirarki sifatnya.

Untuk mengetahui hirarki nilai, Scheler menyuguhkan lima kriteria, yaitu sebagai berikut.

1) Makin lama sebuah nilai bertahan, makin tringgi kedudukannya. Misalnya, kebahagiaan bertahan lebih lama daripada rasa nikmat, kesehatan dari rasa kenyang.

2) Semakin tinggi nilai maka ia tidak dapat dan tidak perlu "dibagi" kalau disampaikan kepada orang lain. Misalnya nilai pengetahuan lebih tinggi daripada makanan karena pengetahuan dapat disampaikan tanpa harus dibagi sedangkan makanan tidak. Tetapi pengetahuan dapat disampaikan utuh kepada sekian banyak orang.

3) Nilai makin tinggi makin ia mendasari nilai-nilai lain dan sendiri tidak berdasarkan niali lain. Misalnya nilai yang berguna berdasarkan nilai yang menyenangkan.

4) Makin dalam kepuasan yang dihasilkan oleh sebuah nilai, makin tinggi kedudukannya. Misalnya, cinta sejati lebih mendalam daripada nikmat seksual; nikmat seksual tidak membantu orang dalam menghadapi maslah-masalah hidup sedangkan orang yang mencintai juga lebih kuat dalam segala tantangan.

5) Makin relatif sebuah nilai, makin rendah kedudukannya, makin mutlak, makin tinggi. Sebuah nilai itu relatif semakin ia hanya masuk akal dalam kaitan dengan jenis realitas tertentu. Misalnya, nilainilai kesenangan dan vital hanya dapat terwujud bagi makhluk yang jasmani-indrawi dan bukan bagi roh murni. Sedangkan nilai kebenaran tidak tergantung dari adanya makhluk jasmani-indrawi. Maka nilai kebenaran lebih tinggi daripada nilai kesehatan (Zaprulkhan, 2016).

Dalam konteks ini, manusia bertindak dengan etis dan merealisasikan nilai kebaikan moral, apabila ia selalu memilih nilai yang lebih tinggi terhadap yang lebih rendah. Lebih jauh dalam pandangan Scheler, manusia bertindak secara moral, apabila berhadapan dengan berbagai kemungkinan untuk bertindak lalu memilih nilai yang lebih tinggi. Jadi, yang menjadi tujuan kemauan orang bermoral adalah pencapaian nilai-nilai dan nilai-nilai moral teralisasi apabila manusia memilih nilai yang lebih tinggi.

\section{d. Pengetian Ilmu Pengetahuan}

Dalam bahasa Arab, kata ilmu jamaknya "ulum" yang berarti ilmu pengetahuan (Muhammad Yunus, 1980). Adapun pengertian pengetahuan menurut Kamus Umum Bahasa Indonesia adalah tahu, atau hal mengetahui sesuatu, segala apa yang diketahui, kepandaian atau segala apa yang diketahui atau akan diketahui berkenaan dengan sesuatu hal (mata pelajaran) (W. J. S. Poerwadarminta, 1991).

IImu merupakan hasil cipta seseorang yang dikomunikasikan dan dikembangkan secara terbuka oleh masyarakat. Jika seandainya hasil cipta tersebut memenuhi kriteria-kriteria keilmuwan maka akan dia dianggap sebagai bagian dari kodifikasi ilmu yang dimanfaatkan oleh masyarakat.

Menurut Archie J. Bahm, pengetahuan yang dapat disepakati sehingga menjadi suatu "ilmu" dapat diuji dengan enam komponen utama yang disebut dengan six kind of science, yang meliputi problem, attitude, method, activity, conclusions dan effect (Mohammad Adib, 2010).

Pengetahuan yang telah berkembang dapat dipertanggungjawabkan kebenarannya menjadi ilmu. Sedangkan ilmu terkandunng pengetahuan yang pasti, sistenmatik, metodik, ilmiah dan mencakup kebenaran umum mengenai objek studi yang bersifat natural yang diperoleh melalui metode-metoden ilmiah. Pengetahuan sesungguhnya hanyalah merupakan produk atau hasil dari sesuatu aktivitas yang dilakukan oleh manusia.

IImu merupakan salah satu cara untuk memperoleh pengetahuan yang objektif dan dapat 
diuji kebenarannya serta harus diupayakan melalui aktivitas manusia. IImu tidak cukup hanya dengan menetapkan fenomena-fenomena saja melainkan berupaya mencari hubungan sebab akibat dari fenomena-fenomena yang terjadi. IImu ditemukan secara individual (perseorsangan) namun dimanfaatkan secara social serta merupakan pengetahuan umum dimana teori ilmiahnya ditemukan secara individual dikaji, diulangi, dan dimanfaatkan secara bersama-sama.

Ilmu pada hakikatnya berasal dari pengetahuan, namun sudah disusun secara sistematik dan diuji kebenarannya menurut metode ilmiah dan dinyatakan valid atau shahih.Sedangkan pengetahuan adalah segala sesuatu yang diketahui namun belum disusun secara sistematik dan belum diuji kebenarannya menurut metode ilmiah serta belum dinyatakan valid atau shahih.

Menurut A.B. Shah menjelaskan terkait ciri-ciri ilmu pengetahuan yang bersifat ilmiah, yaitu sebagai berikut.

1) Memiliki objek yang jelas berupa fenomena alam ataupun sosial.

2) Menggunakan metode yang jelas berupa observasi dan eksperimen.

3) Telah disusun secara sistematik dan komprehensif.

4) Rasional, yakni mengandung premis, postulas, preposisi yang masuk akal.

5) Sudah dapat diverifikasi atau dibuktikan kebenarannya di laboratorium.

6) Bersifat universal, yakni bahwa yang ditetapkan dalam teori tersebut dapat digunakan untuk menjelaskan semua fenomena yang sama dan diterima semua ahli.

7) Memiliki time response yang jelas.

8) Terkait pada hukum-hukum yang serba pasti (A. B. Shah, 1986).

Berdasarkan penjelasan di atas dapat disimpulkan bahwa Ilmu pengetahuan dimaknai sebagai suatu pengetahuan tentang objek tertentu yang disusun secara sistematis sebagai hasil penelitian dengan menggunakan metode ilmiah. Atau dapat juga dikatakan bahwa ilmu pengetahuan merupakan sekumpulan pengetahuan berdasarkan teori-teori yang disepakati dan dapat secara sistematis diuji dengan seperangkat metode yang diakui dalam bidang ilmu tertentu. Dengan demikian, ilmu pengetahuan secara harfiah berarti pengetahuan yang bersifat ilmiah.

\section{e. Telaah IImu Pengetahuan}

Pada hakikatnya pengetahuan merupakan segala sesuatu yang diketahui mengenai suatu objek tertentu baik yang berasal dari pengalaman indra, nalar, otoritas, intuisi, keyakinan maupun dari wahyu.sekaligus merupakan khazanah kekayaan mental yang secara langsung maupun tidak langsung dapat mensejahterakan kehidupan manusia.

Berbicara tentang pertumbuhan dan perkembangan ilmu pengetahuan merupakan sebuah proses yang cukup panjang dimana setiap fase perkembangan ilmu pengetahuan memiliki karakteristik dan ciri tersendiri disetiap zamannya. Karakteristik ilmu tersebut tidak bisa dilepaskan dari proses pembauran budaya yang terjadi dalam perkembangan social di masyarakat. Baik dipengaruhi oleh faktor sosial, politik serta budaya yang selalu mengikuti perkembangan seiring dengan kemajuan ilmu pengetahuan dan teknologi.

Dalam konsepsi agama, ilmu pengetahuan lahir sejak diciptakannya manusia pertama, yaitu Adam. Lalu kemudian berkembanglah menjadi sebuah ilmu pengetahuan yang lahir karena adanya rasa ingin tahu yang muncul dalam diri setiap insan akibat adanya tuntutan dan kebutuhan dalam kehidupan manusia yang terus mengalami perkembangan. Berkembangnya ilmu pengetahuan di setiap masa atau rentang waktu disebakan oleh paradigma berpikir manusia yang telah berubah dari kepercayaan-kepercayaan atau mitos-mitos menjadi lebih rasional (George J. Mouly, 1991: 87). Terkait hal ini, maka para ilmuwan menjadikan filsafat ilmu sebagai suatu alat atau metode untuk mengembangkan ilmu pengetahuan. Setiap aktivitas hanya dapat mencapai tujuannya bilamana dilaksanakan dengan metode yang tepat. Hanya manusia yang berilmu (ilmuwan) yang memiliki kemampuan rasional untuk melakukan aktivitas kognitif (menyangkut pengetahuan) den selalu mendambakan berbagai tujuan yang berkaitan dengan ilmu.

Berdasarkan uraian di atas, dapat dipahami bahwa seorang ilmuwan memiliki peran dan tanggung jawab moral dan sosial yang tidak hanya sekedar menjadi bagian dari warga masyarakat yang memiliki kepentingan secara langsung di masyarakat akan tetapi yang terpenting adalah bagaiamana kemudian seseorang yang berilmu mempunyai peran khusus serta memberikan manfaat dalam keberlangsungan hidup di masyarakat. Seorang ilmuwan diharapkan dapat mentransfer ilmu yang dimilikinya kepada orang lain agar bermanfaat kepada banyak orang sehingga keberadaannya tidak hanya sekedar melakukan pengkajian semata yang manfaat keilmuwannya hanya dirasakan oleh segelintir orang atau secara personal namun juga bertanggung jawab agar produk keilmuwan yang dimilikinya dapat dirasakan dan dimanfaatkan oleh masyarakat.

Sikap sosial seorang ilmuwan adalah konsistensi dengan proses penelaahan keilmuwan yang dilakukan. Sering dikatakan orang bahwa ilmu itu terbatas dari sistem nilai. IImu itu sendiri netral dan para ilmuwanlah yang memberinya nilai. Dalam hal ini, maka masalah apakah ilmu terikst atau 
bebas dari nilai-nilai tertentu semuanya tergantung pada langkah-langkah keilmuwan yang bersangkutan (Jujun S. Suriasumantri, 2010).

Kehadiran filsafat ilmu digunakan untuk mengkaji sejauh mana nilai signifikansi dan aktualisasi berbagai ilmu pengetahuan dalam kehidupan masyarakat. IImu harus diupayakan dengan berbagai kegiatan manusia yang dengan menggunakan metode tertentu yang kemudian aktivitas metodis tersebut mendatangkan pengetahuan yang sistematis. Kesatuan dan interaksi di antara aktivitas, metode dan pengetahuan yang kemudian tersusun menjadi suatu ilmu dapat digambarkan dalam suatu bagan segitiga sebagai berikut.

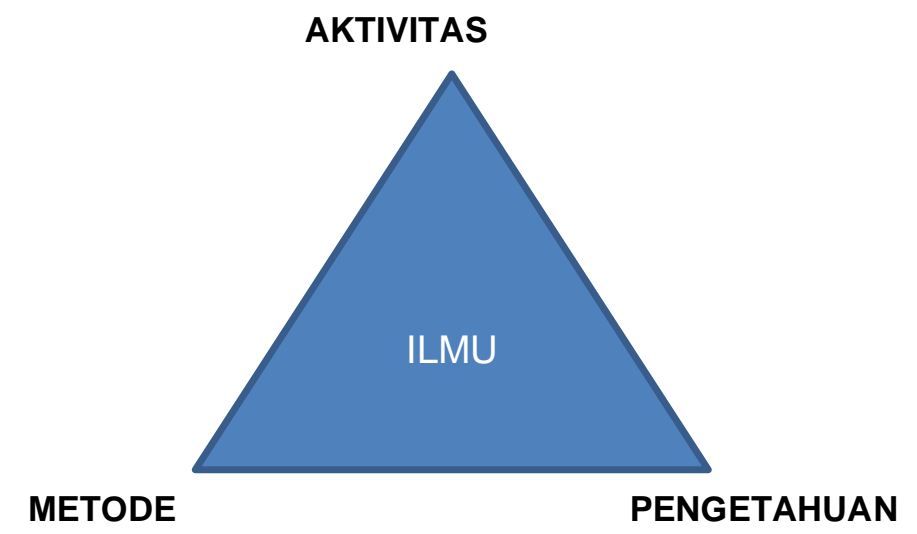

Gambar 1. Aktivitas, Metode, dan Pengetahuan Menjadi Suatu IImu

Berdasarkaan bagan tersebut diatas, dapat dipahami bahwa ilmu merupakan suatu rangkaian aktivitas manusia yang bersifat rasional dan kognitif dengan berbagai metode sehingga menghasilkan akumulasi pengetahuan yang sistematis untuk mencapai kebenaran. Sekitar abad 6 Sebelum Masehi sampai dengan sekitar abad 6 M. Sejalan dengan berkembangnya waktu, filsafat dijadikan sebagai paradigma berfikir oleh bangsa Yunani untuk mengkaji ilmu pengetahuan sehingga perkembangannya sampai pada generasi penerus setelahnya. Dimana hingga saat ini perkembangan ilmu pengetahuan dengan berbagai macam disiplin keilmuan dapat dirasakan pengaruhnya oleh semua umat manusia. Karena itu periode perkembangan filsafat Yunani merupakan entri point untuk memasuki peradaban baru umat manusia.

Proses penelusuran dan pencarian pengetahuan yang bersifat mutlak dan pasti telah berlangsung begitu lama. Setidaknya ada tiga pendekatan metode yang digunakan dalam konteks ini, yaitu rasionalisme, empirisme dan metode ilmiah. Ketiga pendekatan inilah yang biasa dikenal sebagai sebuah metodologi dalam mencari pengetahuan

Periode Yunani kuno disebut periode filsafat alam karena pada periode ini ditandai dengan munculnya ahli pikir alam dimana arah dan perhatian pemikirannya pada alam sekitarnya. Filsafat Yunani muncul dari pengaruh mitologi, mistisisme, matematika, dan persepsi yang kental sedemikian rupa sehingga segalanya nyaris tidak jelas dan seakan mengacaukan pandangan dunia. Kebudayaan mereka kaya dan kreatif namun dikelilingi oleh orang-orang yang spostif dan kompetitif (Mohammad Adib, 2010).

\section{1) Periode Islam}

Joseph Schumpeter menunjukkan dalam mahakaryanya bahwa ada celah besar dalam sejarah pemikiran ekonomi 5000 tahun, yang merupakan periode yang dikenal sebagai Abad Kegelapan. Masa kelam di Barat sebenarnya merupakan masa gemilang bagi umat Islam, inilah yang coba disembunyikan oleh Barat, karena saat ini pemikiran-pemikiran para ekonom Muslim banyak diadopsi oleh para ekonom Barat (Joseph A. Schumpeter, 1954), (Adiwarman A. Karim, 2007).

Saat itu ilmu pengetahuan berkembang sangat pesat di wilayah yang dikuasai Islam. Dan Eropa abad pertengahan lebih memperhatikan masalah agama. Oleh karena itu, peradaban dunia Islam melakukan penerjemahan besar-besaran terhadap tulisan-tulisan para filosof Yunani dan berbagai penemuan di bidang keilmuan lainnya.

Sekitar abad 6-7 Masehi, obor kemajuan ilmu pengetahuan berada di pangkuan Islam. Dimana pada masa ini telah lahir para ilmuwan muslim terkemuka diantaranya, Al-Hawi, Rhazas, Ibnu Sina, al-Khawarizm, Ibnu Rusyd, Al-Idris, Jabir ibn Hayyan, al-Biruni, al-Kindi, al-Farabi, Ibnu Bajah al-Gazali. 
Seiring dengan perkembangan ilmu pengetahuan yang sangat maju dan pesat serta munculnya para ilmuwan, perdaban Islam menjadi pusat peradaban terutama pada masa pemerintahan Daulah Umaiyah, Abbasiyah dan Fatimiyah. Kemajuan ini membawa Islam pada masa keemasannya dan pada saat yang sama, wilayah-wilayah yang jauh diluarkekuasaan Islam masih berada pada masa kegelapan peradaban (dark age). Proses penerjemahan karya-karya filsuf Yunani ke dalam bahasa Arab sangat maju dengan pesatnya (Ayi Sofyan, 2010). Peradaban inilah menjadi cikal bakal perkembangan renaisans di dunia barat.

\section{2) Periode Renaisans dan Modern}

Renaisans adalah periode perkembangan peradaban manusia yang terletak diujung atau sesudah abad kegelapan sampai muncul abad modern. Renaisans merupakan era sejarah yang penuh dengan kemajuan dan perubahan yang berarti bagi perkembangan ilmu pengetahuan. Ciri utama renaisans yaitu humanism, secularism, individualisme, dan rasionalisme. Sains berkembang karena semangat dan hasil empirisisme, sementara Kristen semakin ditinggalkan karena semangat humanismenya.

Pengaruh ilmu pengetahuan Islam yang terus berlanjut di Eropa sejak abad ke-12 menyebabkan kebangkitan kembali warisan Yunani di Eropa pada abad ke-14. Perkembangan pemikiran Yunani di Eropa melalui kajian terjemahan bahasa Arab dan kemudian penerjemahan kembali ke bahasa Latin. Meskipun Islam akhirnya diusir dari Spanyol dengan cara yang sangat kejam, ia mengurus gerakan penting Eropa. Gerakan-gerakan tersebut adalah kebangkitan budaya Yunani klasik (Renaissance) pada abad ke-14, rasionalisme pada abad ke-17, dan Pencerahan pada abad ke-18 (K. Bertens, 1986).

\section{3) Periode Kontemporer}

Periode kontemporer berawal dari abad 20 Masehi dan terus berlangsung sampai saat ini yang ditandai dengan kemajuan teknologi yang serba modern dan canggih serta perkembangan ilmu pengetahuan yang semakin maju dan beraneka ragam. Pada periode ini ilmu fisika menempati kedudukan paling tinggi dan menjadi perbincangan oleh para filosof serta menjadi titik pusat perkembangan ilmu pada masa ini. Hal ini dikarenakan ilmu fisika dianggap sebagai basic ilmu pengetahuan yang materinya mengandung unsur-unsur yang sangat vital dalam membentuk alam semesta. Sebagian besar aplikasi ilmu dan teknologi di abad 21 merupakan hasil penemuan mutakhir di abad 20. Fisikawan yang paling terkenal pada abad ke-20 adalah Albert Einstein, yang mengemukakan teori relativitas dan juga banyak menyumbang bagi pengembangan mekanika kuantum, mekanika statistic dan kosmologi (Surajiyo, 2007).

Berbagai perbedaan pemikiran antara zaman kontemporee dan zaman modern menjadi wujud dari perubahan itu sendiri, dimana pada zaman modern corak pemikiran yang berlandaskan pada metode induktif-deduktif (menggabungkan metode induktif dari Bacon dan metode induksi dari Aristoteles). Sehigga terwujud sinkronisasi dalam pohon ilmu pengetahuan yang dihubungkan dengan pengamatan dan hiporesis. Kemudian secara deduktif hipotesis ini dihubungkan dengan perkembangan pengetahuan yang ada untuk melihat signifikansi dan implikasinya (Mohammad Adib, 2010).

Perkembangan dan kemajuan ilmu pengetahuan harus dibarengi dengan nilai-nilai spritualitas yang tinggi disebabkan ilmu pengetahuan bebas nilai sehingga sangat tergantung dan dipengeruhi oleh bagaimana maanusia itu sendiri mempergunakan dengan sebaik-baiknya. IImu pengetahuan dapat memberikan pengaruh postif sebaliknya juga bisa memiliki pengaruh negative bagi manusia. Pengaruh positif dari kemajuan ilmu pengetahuan adalah dapat memberikan kemudahan serta waktu yang digunakan untuk memperoleh informasi lebih efisien serta memberikan kenyamanan bagi manusia dalam melaksanakan aktivitasnya. Sebaliknya kemajuan ilmu pengetahuan juga dapat membawa malapetaka yang dapat menggerogoti serta mengancam pergerseran nilai baik kemanusiaan, moral maupun agama dalam kehidupan umat manusia.

\section{f. Manfaat IImu Pengetahuan bagi Manusia}

Nilai dan ilmu kegunaannya secara moral dapat dilihat apakah berguna untuk peningkatan kualitas kesejahteraan dan kemashlahatan umat manusia atau tidak. Nilai-nilai bertalian dengan apa yang memuaskan keinginan atau kebutuhan seseorang, kualitas dan harga sesuatu atau appreciative responses. (Mohammad Adib, 2010).

IImu pengetahuan memiliki banyak fungsi, tergantung bagaimana manusia menggunakannya (Abuddin nata, 2018). Adapaun fungsi ilmu adalah sebagai berikut.

Pertama, ilmu alam berfungsi sebagai dasar bagi pembentukan dan pengembangan teknologi yang merupakan konsep, gagasan, pemikiran dan idenya yang bersifat nonfisik atau yang bersifat software (perangkat lunak). Berbagai produk teknologi tersebut dapat memberikan 
berbagai kenyamanan bagi kehidupan manusia baik dalam berkomunikasi, bepergian, mendapatkan berbagai keperluan hidup, air, udara, bahan makanan, minuman, pakaian, pendidikan, kesehatan, hiburan, keamanan dan lain sebagainya, maka berarti telah meberikan rahmat bagi umat manusia. Karena produk teknologi berdasar pada ilmu pengetahuan, maka yang memberi rahmat sesungguhnya adalah ilmu pengetahuan.

Karena ilmu pengetahuan dihasilkan dari kajian terhadap alam jagat raya dengan menggunakan pancaindera dan akal pikiran yang diciptakan dan diberikan Tuhan, maka dalam pandangan Islam yang memberi rahmat itu pada hakikatnya adalah Tuhan. Dengan pandangan yang demikian itu, maka dalam Islam, ilmu pengetahuan dan teknologi harus di pergunakan dan dimanfaatkan dalam rangka beribadah kepada Allah SWT. Masyarakat dalam hal ini harus mampu menentukan teknologi mana saja yang akan dipergunakan dan teknologi mana yang tidak mau dipakai. Secara konseptual, bahwa masyarakat harus menetapkan strategi pengembangan teknologinya agar tidak bertentangan dengan nilai-nilai budaya yang dijunjungnya.

Kedua, ilmu alam berfungsi sebagai penjelasan atas segala hal yang terjadi. Di dalam kehidupan sehari-hari terdapat berbagai peristiwa atau kejadian yang membutuhkan penjelasan. Misalnya terjadi tanah longsor, banjir bandang, tsunami dan sebagainya. Dari aspek teologis, kaum agamis akan memandang bahwa musibah yang terjadi tidak lepas dari akibat perbuatan yang dilakukan oleh manusia itu sendiri. Berdasarkan keyakinan agama dengan menghubungkan azab dari Tuhan akibat perbuatan dosa yang dilakukan oleh manusia. Sehingga jika hal ini diyakini penyebabnya maka solusinya adalah melakukan muhasabah diri dilanjutkan dengan permohonan ampun kepada Allah dan segera bertobat dan melakukan perbuatan terpuji dan amal ibadah. Sedangkan seorang ilmuwan akan memberikan penjelasan atas musibah yang dialami oleh manusia berdasarkan pendekatan ilmiah, yaitu dengan mencari sebab - sebab atau hukum kausalitas yang dapat diamati, diprediksi atau dapat diramalkan, sebagaimana hal ini biasa terjadi pada berbagai temuan dalam bidang ilmu pengetahuan, yakni adanya hukum-hukum yang mendasari sebuah teori ilmu pengetahuan. Terjadinya tanah longsor misalnya, dijawab dengan mengatakan sebagai akibat dari adanya rongga-rongga atau perenggangan pada tanah yang terjadi di musim kemarau yang kemudian rongga-rongga atau bagian yang renggang pada tanah tersebut terisi air hujan sedangkan pada bagian kiri kanan tanah tersebut tidak terdapat pohonpohon atau dinding yang menghalanginya, maka terjadilah tanah longsor. Cara mengatasinya adalah dengan menanami pohon-pohon pada tanah tersebut sehingga tidak terjadi rongga-rongga atau perenggangan pada tanah tersebut.

Ketiga, ilmu berfungsi sebagai penerang atau nur bagi kehidupan manusia. Keberlangsungan masa depan suatu bangsa sangat dipengaruhi oleh tingkat penguasaan bangsa tersebut terhadap ilmu pengetahuan. IImu sebagai cahaya mensyaratkan kebersihan diri bagi orang yang akan mendapatkannya. IImu sebagai cahaya ini dapat pula dipahami dari adanya kehendak Tuhan yang memberikan cahaya kepada orang yang dikehendakinya. Sebagaimana dijelaskan dalam Qur'an surah An-Nur (24) ayat 35.

IImu sebagai cahaya erat kaitannya dengan orang yang berjalan di tengah malam, kemudian ada orang yang memberikan obor sehingga jalan yang dilaluinya tampak jelas dan terang benderang. Hal ini erat sekali dengan peran dan fungsi ilmu baik ilmu yanglangsung datang dari Tuhan (ilmu al-hudluri) maupun ilmu yang diusahakan manusia (ilmu al-hushuli). Sebagaimana arti dari sebuah ilmu secara bahasa yakni alamat, tanda, dan simbol maka semuanya akan menjadi penerang dan penjelas bagi manusia tentang arah yang akan dituju.

Keempat, ilmu berfungsi sebagai pondasi yang akan menyangga benteng peradaban sekarang ini sekaligus merupakan alat untuk meningkatkan kualitas hidup manusia.

Kelima, ilmu berfungsi sebagai alat untuk meningkatkan harkat dan martabat. IImu pengetahuan, khususnya yang berkaitan dengan etika, akhlak, adab, sopan santun, dan moral yang menempatkan manusia sebagai makhluk yang mulia dan harus saling memuliakan demikian juga dengan makhluk ciptaan lainnya.

Di tengah maraknya dunia global dengan perkembangan ilmu pengetahuan dan teknologi yang sangat maju, umat Islam akan mampu memiliki keunggulan dan daya saing yang tinggi sebagaimana halnya dengan orang-orang barat manakala mampu mentransformasikan dan menyapa secara aktual terhadap ilmu pengetahuan dalam rangka memahami wahyu, atau mampu memahami wahyu dalam mengembangkan ilmu pengetahuan (Arman Arief, 2005).

Dilihat dari aspek aksiologis, ilmu pengetahuan dan teknologi harus mampu memberikan kemashlahatan bagi kehidupan manusia. Oleh karena itu, ilmu dan teknologi harus memberikan berkah serta anugerah yang tak terhingga bagi kehidupan umat manusia.

Berbagai keuntungan yang akan diperoleh manusia berkat ilmu pengetahuan yang dilandasi iman dan takwa kepada Allah SWT, sebagimana dinyatakan dalam firman Allah SWT surah alMujadilah (58) ayat 11.

Pernyataan dan janji Allah SWT melalui ayat di atas dapat di pahami bersama bahwa orang 
yang berilmu lebih merasakan keberkahan dibandingkan dengan orang yang tidak berilmu. Dimana orang yang berilmu tampak lebih berbudaya dan berakhlak dibandingkan dengan yang tidak berilmu. Dengan demikian, maka tidaklah mengherankan jika Allah SWT mewajibkan manusia untuk menuntut ilmu pengetahuan, menumbuhkan, membina dan mengembangkannya melalui kegiatan penelitian dalam arti seluas-luasnya serta menyebarkan dan memanfaatkan ilmu tersebut untuk mengsejahterakan kehidupan umat manusia.

\section{Simpulan}

Berdasarkan uraian dan analisis sebagaimana dijelaskan pada makalah ini, maka dapat dikemukakan simpulan sebagai catatan penutup dari aspek aksiologi ilmu dari filsafat mengkaji tentang fungsi ilmu untuk memberikan petunjuk, solusi, pikiran ilmiah dan pembebas dari kebodohan. IImu pengetahuan adalah pengetahuan ilmiah yang memiliki ciri-ciri: dapat diamati, (empiris), dapat diuji, objektif dalam arti tidak memiliki muatan rasa atau emosional serta bersifat universal. Ilmu pengetahuan di barat bersifat netral, tidak memiliki tujuan yang melekat pada dirinya sendiri melainkan sangat bergantung pada manusia yang menggunakannya.IImu pengetahuan dalam Islam selain bertujuan untuk memberikan kemashlahatan bagi kehidupan manusia juga untuk semakin memperkuat keimanan dan ketakwaan kepada Allah SWT.

\section{DaftarPustaka}

Adib Mohammad. 2010. Filsafat IImu Ontologi, Epistemologi, Aksiologi dan Logika Ilmu Pengetahuan, Yogyakarta: Pustaka Pelajar.

Arief Arman. 2005. Reformasi Pendidikan Islam. Jakarta: CRSD Press.

Bagus Lorens. 2002. Kamus Filsafat. Jakarta: Gramedia.

Bakhtiar Amsal. 2013. Filsafat IImu. Jakarta: Raja Grafindo Persada.

Bertens K. 1986. Ringkasan Sejarah Filsafat. Yogyakarta: Kanisius.

Echols John M dan Hassan Shadily. 1980. Kamus Inggris-Indonesia, Jakarta: Gramedia.

Hamdani (2019), Aksiologi IImu Pengetahuan Dan Keislaman (Interkoneksi Nilai-Nilai Keislaman) AlIbrah, Vol. 4 No. 2, 1.

Hunnex Milton D.2004. Peta Filsafat, Terj. Zubair. Jakarta: Teraju.

Kattsoff Louis. 2004. Pengantar Filsafa; Penerjemah: Soejono Soemargono. Yogyakarta: Tiara Wacana Yogya.

Mouly George J. 1991. Perkembangan ilmu, IImu dalam Perspektif: Sebuah Kumpulan Karangan Tentang Hakekat IImu, Jujun S. Suriasumantri. Jakarata: Gramedia.

Mudhofir Ali. 2001. Pengenalan Filsafat Dalam Filsafat IImu Sebagai dasar Pengembangan IImu Pengetahuan. Yogyakarta: Liberty.

Nata Abuddin. 2018. Islam dan IImu Pengetahuan, Jakarta: Prenadamedia Group.

Poerwadarminta W. J. S. 1991. Kamus Umum Bahasa Indonesia. Jakarta: Balai Pustaka.

Said Nurman. 2005. Wahyuddin Halim, Muhammad Sabri, Sinergi Agama dan Sains. Makassar: Alauddin Press.

Schumpeter Joseph A.1954. A history of Economic Anallysis. Newyork: Oxfoed University Press, 1954.

Shah A. B. 1986. Metodologi Ilmu Pengetahuan. Jakarta: Yayasan Obor Indonesia.

Sofyan Ayi. 2010. Kapita Selekta Filsafat. Bandung: Pustaka Setia.

Suhartono Suparlan. 2011. Filsafat IImu Pengetahuan. Yogyakarta: Ar-Russ Media.

Surajiyo. 2007. Filsafat Ilmu dan Perkembangannya di Indoensia: Suatu Pengantar. Jakarta: Bumi Aksara.

Suriasumantri Jujun S. 2010. Filsafat Ilmu Sebuah Pengantar Populer. Jakarta: Pustaka Sinar Harapan. Yunus Muhammad. 1980. Kamus Arab-Indonesia. Jakarta: Gramedia.

Zaprulkhan. 2016. Filsafat IImu Sebuah Analisis Kontemporer. Jakarta: PT. Raja Grafindo Persada. 